\title{
Management of Vandhyatwa with Chitrakadi Ghrutam and Phala Ghrutam
}

\author{
Research article
}

\section{Bhaskaruni Subbalakshmi $^{1^{*}}$, Meera Madhukar Paranjape ${ }^{2}$}

1. Professor, Department of Prasuti and stree roga,

DR. B.R.K.R. Govt. Ayurvedic College, Hyderabad, (A.P)

2. Professor, Department of Stree roga and Prasuti, Astanga Ayurveda Mahavidyalaya, Pune

\begin{abstract}
Failure to achieve conception is Vandhyatwa (Infertility). The present research work is on stree vandhyatwa (female infertility). Clinical study conducted with Chitrakadighrutam oral in A group 50 patients and Phala ghrutam oral in B group 50 patients of Vandhyatwa. Efficacy of Chitrakadi ghrutam oral in management of stree vandhyatwa (female infertility) in comparison with Phala ghrutam is studied and assessed. Group A patients are given Chitrakaadi ghrutam - 10gms. oral once a day - at 6 a.m. Group B patients are given Phala ghrutam - 10gms. oral once a day - at 6 a.m. for 3 months. Anupaanam - is $100 \mathrm{ml}$ luke warm water. Follow up was done for the drug once in one month. Further follow up was done once in a month for one year. Both the drugs proved to be effective in the management of the Vandhyatwa, but Chitrakadi ghrutam proved more efficacious than the Phala ghrutam.
\end{abstract}

Key words: Chitrakadi ghrutam, Phala ghrutam, Stree vandhyatwa, Menstrual cycles, Ovulation and Conception.

\section{Introduction:}

It is bless to have children with routine marital life. Otherwise the person is Bhishajita - means the persons who won't get children with their routine marital life are for the medication (1). SHE / STREE is the placement for a human being before entering into the world. Charakacharya emphasized the importance of the child (Apatya) - in the context of the Vajikarana for expansion of human race (2). Vitiated yoni (Reproductive system of woman) cannot hold sukra (Sperm) which leads to non occurrence of pregnancy (3).

*Corresponding Author:

\section{Bhaskaruni Subbalakshmi,}

Professor,

Department of Prasuti and stree roga,

DR. B.R.K.R. Govt. Ayurvedic College,

Hyderabad, (A.P)

Contact no: +91-9440240149

Email: subbalakshmi.bhaskaruni@gmail.com
Menstrual disorders (Artava dosha) and absence of gametocyte / Oocyte / Ovum (Abeejam bhavati) leads to non occurrence of pregnancy (Anupa labdhi of garbha ) or infertility (4).

Without vata, yoni (reproductive system) cannot vitiate (5). Dushita yoni causes vandhyatwam (Infertility). "apatya shoonya gouh"- as per Shabda kalpa Druma. Inability to get the conception is described by the name as apraja, sapraja etc. in Ayurvedic literature. But etiopathology for non-occurrence of conception can be compiled from different Ayurvedic classics.

According to Ayurvedic texts defects in rutu (Season), kshetra (place or the uterus), ambu (Nutrients) and beeja (includes shukra and arthava - semen and oocyte) leads to infertility.

Involvement of yoni dosha, artava (upadhatu) dosha, vata etc. dosha dushti are some among those. 


\section{Incidence:}

About $10-15 \%$ of couples are infertile in India. Female infertility is about $40-50 \%$. Male factor is about $40 \%$. Unexplained is about $20 \%$.

Faults in the female for infertility are as follows:

- Tubal and Peritoneal factors are 36 to $44 \%$.

- Ovulatory factors 26 to $44 \%$.

- Endometriosis 1 to $10 \%$.

- Ovarian factors 30 to $40 \%$.

- Tubal factors $40 \%$.

- Uterine factors $10 \%$.

- Cervical factors 5\%

Of the above mentioned factors polycystic ovarian disease (PCODs) are one of the commonest causes of female infertility. Hence, the present study taken up to study the effect of Ayurvedic treatment in the management of Vandhyatwa (PCODs).

\section{Aims and objectives:}

To compare the efficacy of oral administration of Chitrakadi ghrutam and Phala ghrutam in management of stree vandhyatwa (PCODs)

\section{Materials and methods:}

1) Selection of Patients:

100 patients suffering from PCODs were identified by Symptoms like Irregular menstrual cycles, scanty menstruation, heavy bleeding during menstrual periods, Anovulatory cycles and by the investigations like ultrasound scanning. The selected patients were divided into two groups randomly consisting of 50 patients in each group.

Group A patients were given Chitrakadi ghrutam 10 gms orally with luke warm water once in a day at 6 A.M for 3 months.
Group B patients were given Phala Ghrutam 10 gms orally with luke warm water once in a day at 6 A.M for 3 months.

\section{Inclusion criteria:}

1. Age between 20 years to 35 years age.

2. Patients irrespective of cast, religion and socio economic strata.

3. Female infertility due to PCODs.

\section{Exclusion criteria}

1. Age below 20 yrs and above 35 yrs .

2. Male infertility, Tuberculosis specific in fallopian tube.

3. other conditions of infertility like Cervical polyp, Non Co-operative Patients, Endometrial polyp, Intrauterine fibroid or growth, HIV sufferers, Hepatitis B sufferers etc.

\section{Investigations:}

- Complete Blood Picture (CBP), Erythrocyte sedimentation rate (ESR), Complete Urine Examination (CUE), Fasting blood Sugar (FBS),

- Post Lunch Blood Sugar (PLBS),

- VDRL, HbsAG, HIV I \& II, TORCH, Blood Group \& Rh Typing,

- Hystero- Salpingography (HSG),

- Mantoux test,

- Follicular study,

- Post Coital test(PCT),

- Pap smear,

- Thyroid Function test (T3, T4, TSH) etc prior to treatment as per need. Semen analysis test to husband to select the patient.

Place of work: Dr. BRKR. Govt. Ayurvedic College and Hospital Hyderabad

Ingredients of the drugs used:

The drugs used for the study were prepared as per the references from the Textual literature as follows: 
Chitrakadi ghrutam (Susrutha Samhitha Uttara sthana $58^{\text {th }}$ ch. / 63 to 69 ):

The contents of the Chitrakadi ghrutam are as follows:

- Chitraka (Plumbago Zeylanicum - Linn.) - root bark

- Swetha Sariva (Hemidesmus - indicus $R$. $B r$.) - root

- Bala (Sida Cordifolia - Linn) - root, seed

- Nalla Sugandhi (Ichno Carpus frutescens R.) - root

- Draksha (Vitis vinifera Linn.) - Fruit, leaves

- Indravaruni / Vishala (Citrullus Coloegnthis stkard) - fruit, root

- Pippali (Piper Longun Linn.) - fruit, root

- Chitraphala - Pedda papara (Trichosanthes brateata) - fruit, root

- Madhuka (glycyrrhiza glabra Linn.) root

- Hareetakee (Terminalia Chibula Ritz.) fruit

- Amalaki (Emblica officinalis Gaertn.) Fruit, Seed, leaves, Root, Bark \& flowers

- Ksheera

- Ghrita

- Tavakshira (Curcuma angustifolia Roxb.) - Tuber.

Phala ghrutam (Bhavaprakasa uttarakhanda Page - 1154, 1155):

The contents of the Phala ghrutam are as follows:

- Manjishta (Rubia cordifolia Linna.) root

- Madhuka (glycyrrhiza glabra Linn.) root

- Kushtam (Saussuria lappa C. B. Clark.) - root

- Amalaki (Phyllanthus embelica L.) Fruit

- Hareetaki-(Terminalia chebula Retz.)

- Vibheetaki (Terminalia bellarica Roxb.) - fruit

- Sharkara (sugar)

- Bala (Sida Cordifolia Linn.) - root, seed
- Shatavari / Meda dwayam (Asparagus racemosus Willd.) - Tuberous roots

- Payasya (Pueraria tuberose Dc.) rhizome

- Aswagandha / Kakoli dwayam (Withania somnifera Dunal.) - root, leaf, ksharam

- Ajamoda (Carum roxburghianum Spranngue)(Apium gravolens) - seeds

- Haridra (Curcuma longa linn) - tuberous root

- Daru Haridra (Berberis Aristata - Roxb) - root bark, fruit

- Priyangu (Callicarpa Macrophylla Vahl.) - flowers, fruit

- Katurohini (Pitrorhiza kurroa Royle-ExBenth) - root

- Kumuda / Uttpalam (Nymphaea stellata Wiilc.) - root, flower, seed

- Draksha (Vitis vinifera Linn.) - fruit

- Kaakolya / Aswagandha - (Withania somnifera Dunal.) - root, leaf, ksharam

- Chandana (Santalam Albam linn.) - Oil, heartwood

- Shatavari- (Asparagus racemosus Willd.) Tuberous, roots

- Ghrutam (cow ghee)

- Ksheeram. (cow milk)]

\section{Standardization of the drugs:}

Preparation of Ghrutaas are subjected to test of standardization parameters at - Drug Testing Lab, Hyderabad and no objection certificates are obtained to identify authentic samples for study purpose.

\section{Clinical Plan:}

Factors of infertility are confirmed by counselling, clinical features and investigations.

A Group - 50 patients - Subjected to oral Chitrakaadi ghrutam.

B Group -50 patients - Subjected to oral Phala ghrutam.

\section{Assessment Criteria:}

Subjective parameters

1. Regularity of menstrual cycle: 
- Regular - Menstruation between 28-30 days.

- Irregular - Menstruation before 28 days or after 30 days.

2. Menstrual flow:

- Scanty - below 2 pads per day for less than 3 days.

- Normal - 2 to 3 pads per a day for 3 to 5 days

- Excessive - above 3 pads per day for more than 5 days.

3. Presence of PCOD:

- If present in ultrasonography scanning.

- If not seen in ultrasonography.

4. Anovulation: Assessed through follicular study.

- Presence of ovulation
- Absence of ovulation

5. Conception: Assessed through Gravindex test

- Positive test

- Negative test

Treatment duration -3 months.

Follow up period - Once in 1 month for oral drug.

Further follow up was planned once in one month for one year.

\section{Anupaanam -}

$100 \mathrm{ml}$. luke warm water.

Statistical analysis - Statistical analysis was carried out on subjective signs and objective signs by using Chi-square test to assess the Statistical significance.

Observations and results:

Table - 1: Change in menstrual cycle before and after treatment

\begin{tabular}{|l|l|l|l|l|}
\hline \multirow{2}{*}{ Menstrual cycle } & \multicolumn{2}{|l|}{ Group-A } & Group-B \\
\cline { 2 - 5 } & B.T. & A.T. & B.T. & A.T. \\
\hline Irregular & 28 & 8 & 30 & 14 \\
\hline Regular & -- & 20 & -- & 16 \\
\hline P-value & $<0.001$ & $<0.001$ & \\
\hline$\chi^{2}$ & 28.08 & 19.18 & \\
\hline
\end{tabular}

Showing change in mentural cycle in Group-a and Group-B patients

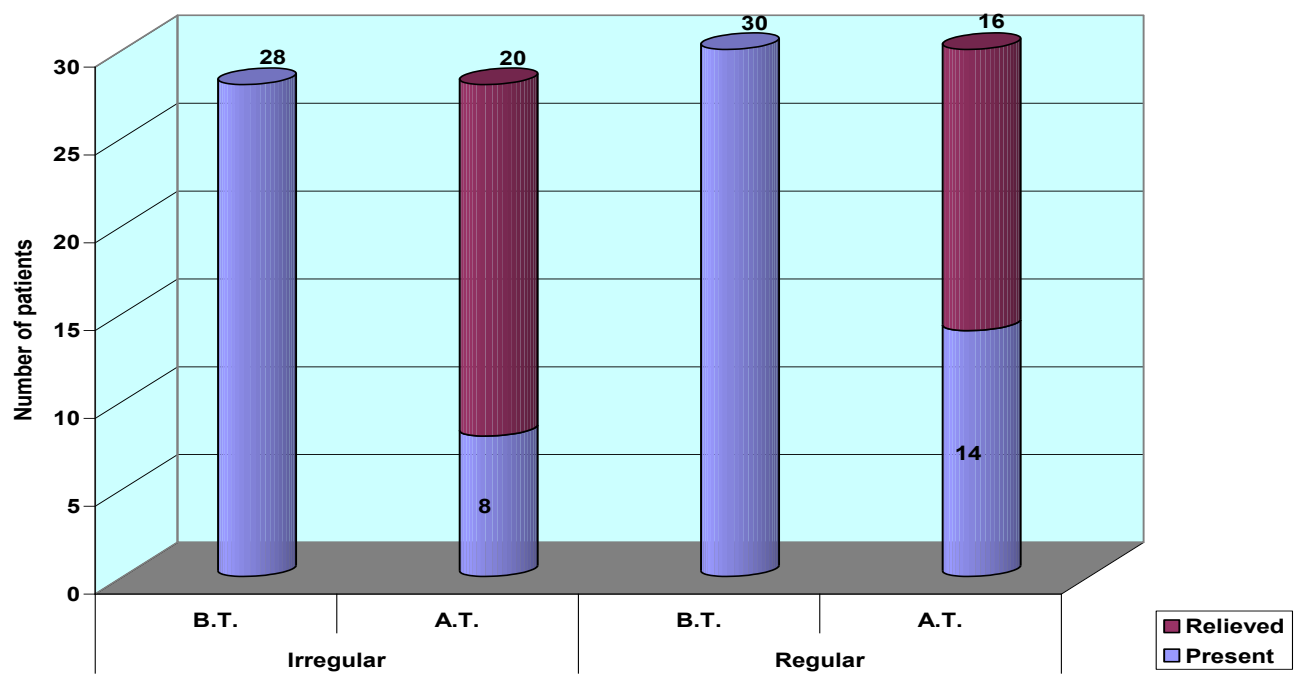


Table - 2: Showing status of menstrual flow at base-line and their relief after treatment in Group A

\begin{tabular}{|c|c|c|c|c|c|}
\hline \multirow{2}{*}{ Group } & \multicolumn{2}{|c|}{ Present in number of patients } & \multirow{2}{*}{ Subsided } & \multirow{2}{*}{$\chi^{2}$-test } & \multirow{2}{*}{$\mathrm{P}<0.05$} \\
\hline & B.T. & A.T. & & & \\
\hline Normal & 35 & $\begin{array}{l}35 \\
12\end{array}$ & $12(80.0 \%)$ & 16.80 & Sig. \\
\hline Scanty & 10 & 2 & -- & -- & -- \\
\hline Excessive & 5 & 1 & -- & -- & -- \\
\hline
\end{tabular}

Table - 3: Showing status of menstrual flow at base-line and their relief after treatment in Group B

\begin{tabular}{|c|c|c|c|c|c|}
\hline \multirow{2}{*}{ Group } & \multicolumn{2}{|c|}{ Present in number of patients } & \multirow{2}{*}{ Subsided } & \multirow{2}{*}{$\chi^{2}$-test } & \multirow{2}{*}{$\mathrm{P}<0.05$} \\
\hline & B.T. & A.T. & & & \\
\hline Normal & 32 & $\begin{array}{l}32 \\
13\end{array}$ & $13(72.2)$ & 17.34 & Sig. \\
\hline Scanty & 12 & 3 & -- & -- & -- \\
\hline Excessive & 6 & 2 & -- & -- & -- \\
\hline
\end{tabular}

Table - 4: Showing present of PCOD at base-line and their relief after treatment in Group A and Group B patients

\begin{tabular}{|l|l|l|l|l|l|}
\hline \multirow{2}{*}{ Group } & Present in number of patients & \multirow{2}{*}{ Subsided } & \multirow{2}{*}{$\chi^{2}$-test } & $\mathrm{P}<0.05$ \\
\cline { 2 - 6 } & B.T. & A.T. & $13(86.7 \%)$ & 19.55 & Sig. \\
\hline Group A & 15 & 2 & $11(78.6 \%)$ & 14.97 & Sig. \\
\hline Group B & 14 & 3 & & \\
\hline
\end{tabular}

\section{Showing PCOD status before and after treatment}

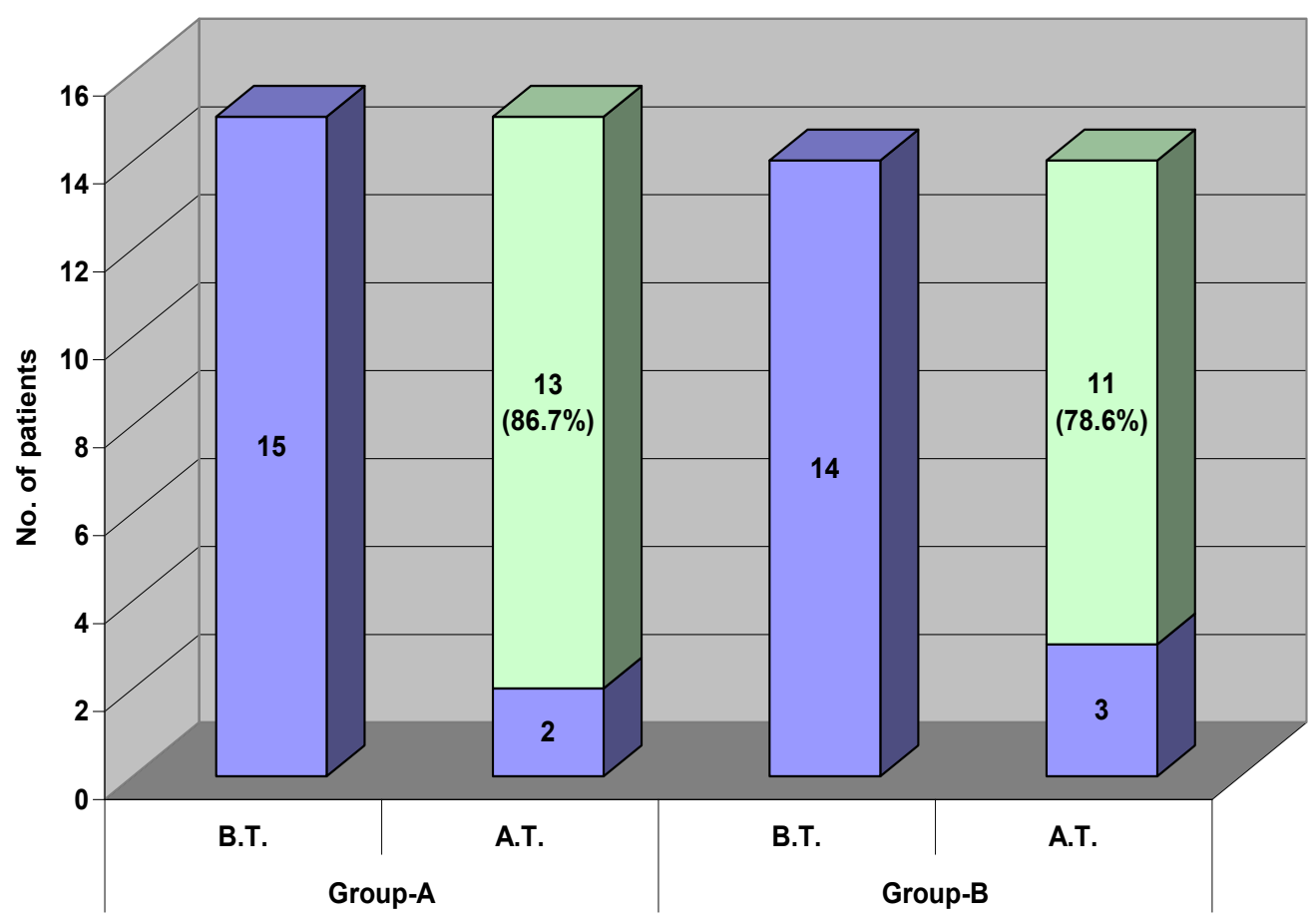


Table - 5: Change in Anovulation status before and after treatment in Group-A and Group-B by GFT.

\begin{tabular}{|l|l|l|l|l|}
\hline \multirow{2}{*}{ Cycle } & \multicolumn{2}{|l|}{ Group-A } & Group-B \\
\cline { 2 - 5 } & B.T. & A.T. & B.T. & A.T. \\
\hline Anovulatory & 30 & 8 & 32 & 14 \\
\hline Ovulatory & -- & 22 & -- & 18 \\
\hline P-value & $<0.001\left(\chi^{2}=31.65\right)$ & $<0.001\left(\chi^{2}=22.34\right)$ \\
\hline
\end{tabular}

Showing changes in ovulation status Group-A and Group-B patients

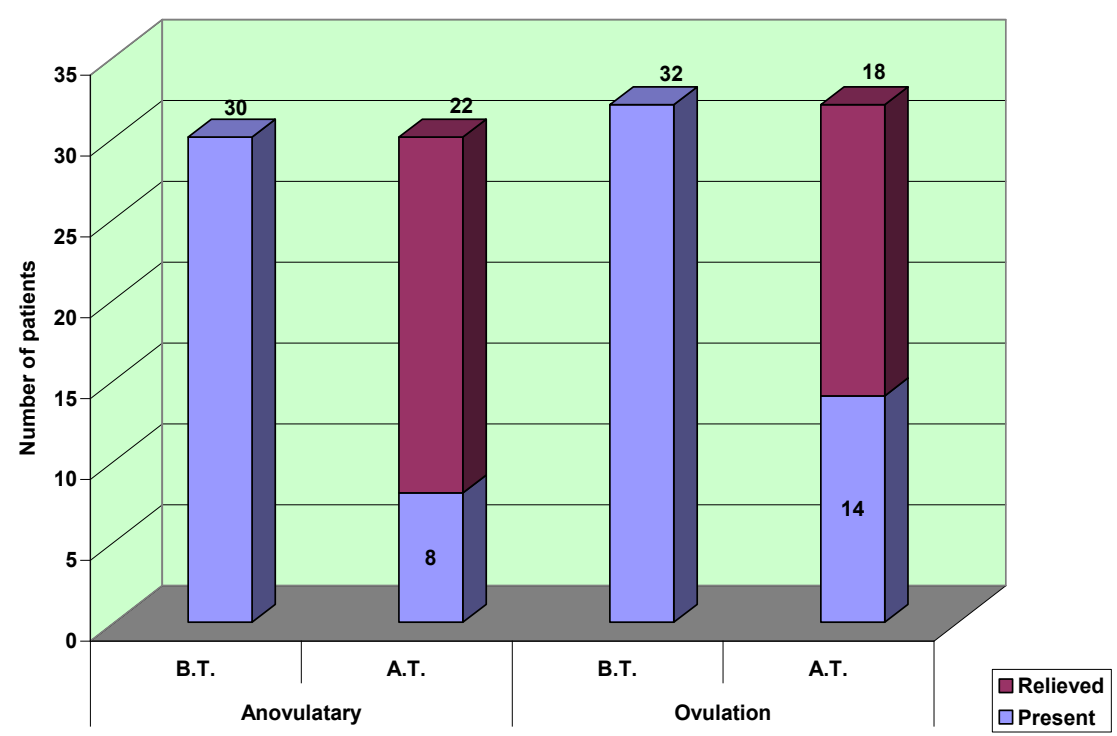

Table - 6: Number of patients conceived in Group-A and Group-B patients

\begin{tabular}{|l|l|l|l|l|}
\hline Group & No. of cases & Conceived (\%) & $\chi^{2}$-test & $\mathrm{P}<0.05$ \\
\hline Group A & 50 & $10(20 \%)$ & 9.00 & Sig. \\
\hline Group B & 50 & $7(14 \%)$ & 5.53 & Sig. \\
\hline
\end{tabular}

Showing number of patients conceived after treatment

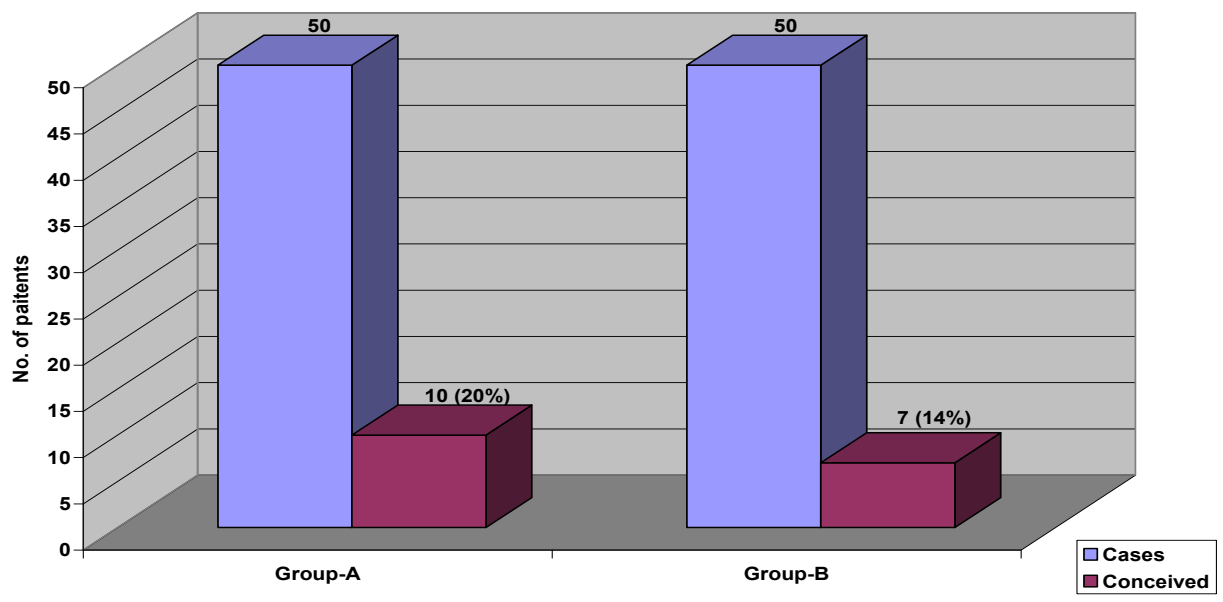

BT - Before Treatment; AT - After Treatment; PCOD - Poly Cystic Ovarian Disorder USG - Ultra Sono Graphy ; GFT - Graffian Follicle Study 


\section{Discussion:}

There is much etiopathology for non-occurring the pregnancy. Yonidosha, Artava or Asruk dosha (Irregular menstrual cycles, abnormal menstrual flow, PCOD, anovulatory cycles), are some among those. According to Ayurveda, Ama (the undigested part of food during conversion from exogenous (sajaateeya) to endogenous (vijaateeya), is responsible for all the disorders. All hormonal enzymatic disorders are considered to be Ama janitha rogas. Bleeding disorders are linked with hormones and Thyroid dysfunction in some patients. Scanty bleeding and heavy bleeding are some among the symptoms of PCOD (Vandhyatwa).

Different symptoms observed in the pathogenesis of the gynaecological disorders are as follows:

Margaavarana of dosha leads to loss of menstruation (8). Vitiation of vata and pitta causes scanty menstruation (9). Pitta vardhaka, rasaayana, vrishya, vatahara etc., property drugs are the remedy for Kseena Artava (scanty menstruation).

Exessive bleeding is the result of Pittaavrita Apana vayu (10). Deepanam, Graahi are the remedy for all apana avruta disorders (11). The ingredients of both the preparations are having the above mentioned properties.

Cyst or tumour (granthi) is one among the vitiated sroto lakshna (12) - can be applied for PCOS. Dushita Ama is due to rasaadi dhaatu janya vyaadhi (13). Being upadhatu of rasa, asruk / artava also vitiates and generates the disorder and this is observed as visible bleeding is the menstruation and invisible part is considered as ovulation. All menstrual disorders, anovulatory cycles are the result of vitiated asruk / artava. Deepana drugs are helpful for the reduction of Ama, improve the agni and thereby reduce the sroto dushti and dosha prakopa (dosha vitiation). Hence Pachana, Grahi dravyas are used to in these conditions.

In sama condition we may not be able to eliminate the doshas with sodhana karma. It is mandatory to use Pachana dravya. By preventing the production of Ama and eliminating the existing Ama, vitiation of dosha and dhatu can be reduced. Vyadhiharam (relieving the disorder) Apatyam (child), Vrushataa (vigority), balam (strength), etc., result can be achieved through Virechana (purgative) property. The potent srotoshodaka dravyas as constituents of medicated ghruta (ghee) is use full as amahara and deepana pachanakari. Formation, maturation and rupture of the follicle together called as ovulation and will take about three months time in healthy individuals. Vrushyadi drugs, prajasthapana drugs are helpful in this process.

Rationality for using the drugs in both the groups is as follows:

In group A patients Chitrakadi ghruta is used and the properties of the drugs used are - Deepana, Paachana (Chitraka); deepani (Pippali) Virechana (Draksha, Chitraphala, Indravaruni), Anulomana (Hareetaki) Rasayana, Vrushya (Madhuka, Amalaki, Tuguksheeri, etc.), Brumhana, Jeevaneeya, Praja sthaapana (Bala, Ghruta etc.), Grahi (Sariba), Rraktapittasamaka (Sarkara) (14) etc. Hence the combined effect is helpful for the reduction of the disease Stree Vandhyatwa with Chitrakadi ghrutam.

In group B patients Phala ghrutam is used and the properties of the drugs used are - Sodhahara (Manjishta, Vibheetaki, Haridra dwayam), Sukrala (Madhuka, Kushta, Aswagandha), Vrishya, Rasayana, Prajasthapana (Sarkara, Bala, Satavari, Ghritam and Ksheeram), Raktadoshahara (Payasya), Deepana (Ajamoda, Vibheetaki), Rechani, Bhedani (Priyangu, Katurohini), Grahi (Utpala, Kumuda), Vishahara (Chandana dwayam), (15) etc. 
The combine effect is helpful for the management of Stree Vandhyatwa.

A total of 100 patients are selected for the clinical study of which 50 patients are grouped as A and given Chitrakadi ghrutam orally and 50 patients are grouped as B and given Phala ghrutam oral.

Chi-square test is applied to statistically prove the efficacy of drugs.

- 20 got regular menstrual cycles of 28 patients of group A group. P-value < $0.001\left(\chi^{2}=28.08\right)$; In 30 patients of $\mathrm{B}$ group 16 got regular cycles. $\mathrm{P}$-value $<$ $0.001\left(\chi^{2}=19.18\right)-$ Highly significant.

- 10 patients are with Scanty bleeding, 5 patients are with excessive bleeding in group A. Total 12 patients became normal. P-value $<0.05\left(\chi^{2}=16.80\right) .12$ patients are with Scanty bleeding, 6 patients are with excessive bleeding in group B. Total 13 patients became normal. P-value $<0.05\left(\chi^{2}=17.34\right)$. It is significant in both the groups.

- PCOD subsided in13 patients of 15 in group A. P-value $<0.05\left(\chi^{2}=19.55\right)$. PCOD subsided in 11 patients for 14 in group B. P-value $<0.05\left(\chi^{2}=14.97\right)$. It is significant in both the groups.

- 22 patients are ovulated for 30 patientsof A group, P-value $<0.001\left(\chi^{2}\right.$ $=31.65) 18$ are ovulated for 32 patients in B group, P-value $<0.001$ $\left(\chi^{2}=22.34\right)$. It is - Highly significant in both the groups.

- As per the Gravindex test 10 patients (20\%) conceived of the 50 cases in A group. P-value $<0.05\left(\chi^{2}=9.00\right) .7$ patients $(14 \%)$ conceived of the 50 cases in B group. P-value $<0.05\left(\chi^{2}=\right.$ 5. 53).

No toxic symptoms reported during treatment/research work.

No complications are observed during the treatment in both groups. About six patients of both groups have complained of belching and were treated with lukewarm water orally and got relieved.

\section{Conclusion}

Action of Chitrakadi ghrutam in management of Vandhyatwa is highly significant in comparison with Phala ghrutam.

\section{Acknowledgement:}

The support received from the Maharashtra University of Health Sciences, Nasik, Faculty of Ayurveda is Acknowledged.

\section{References:}

1. Premvati Tiwari. Ayurveda Prasuti tantra evam Streeroga Part II - Stree roga, $2^{\text {nd }}$ Edition, Varanasi; Choukhambha Orientalia; 2000; Page 272.

2. Charaka. Andhra tatparyasahita Charaka Chikitsasthanam, $4^{\text {th }}$ Edition, Rajamundry;

Sripadakrishnamurty\&sons; 7-111989; Page 45

3. Charaka. Andhra tatparyasahita Charaka Chikitsasthanam, $4^{\text {th }}$ Edition, Rajamundry; Sripadakrishnamurty \& sons; 7-11-1989; Page 702

4. Susruta. Susrutha Samhitha Sareera sthana, $1^{\text {st }}$ Edition, Madras, Vavilla press; V. Venkateswara sastrulu; 1952; page -20 .

5. Charaka. Andhra tatparyasahita Charaka Chikitsasthanam, $4^{\text {th }}$ Edition, Rajamundry; Sripada krishnamurty \& sons; 7-11-1989; page 713.

6. Susruta. Susrutha Samhitha Uttara sthana saandhra tatparyam, $1^{\text {st }}$ Edition, Chennapuri; Vavilla Rama-swami Sastulu \& sons; 1954; page 509, 510.

7. Bhavamisra. Bhavaprakasa madhyamottarakhanda telugu commentary by M.Venkatasastry, $2^{\text {nd }}$ Edition; Vijayawada-2; Sree Panduranga Printing Works; 1959; Page 1154, 1155.

8. Susruta. Susrutha Samhitha Sareera sthana, $1^{\text {st }}$ Edition, Madras; Vavilla press; V. Venkateswara sastrulu; 1952; page 25 
9. Susruta. Susrutha Samhitha Sareera sthana, $1^{\text {st }}$ Edition, Madras; Vavilla press; V. Venkateswara sastrulu; 1952; page 19.

10. Charaka. Andhra tatparyasahita Charaka Chikitsasthanam, $4^{\text {th }}$ Edition, Rajamundry; Sripada krishnamurty \& sons; 7-11-1989; page 672

11. Charaka. Andhra tatparyasahita Charaka Chikitsasthanam, $4^{\text {th }}$ Edition, Rajamundry; Sripada krishnamurty \& sons; 7-11-1989; page 673

12. Charaka. Charaka Vimana sthanam of Andhra tatparyasahita Charaka Sthana Shatkam, $3^{\text {rd }}$ Edition, Rajamundry;
Sripada krishnamurty \& sons; 1989; page 118

13. Charaka. Andhra tatparyasahita Charaka Chikitsasthanam, $4^{\text {th }}$ Edition, Rajamundry; Sripada krishnamurty \& sons; 7-11-1989; Page 351.

14. Madadi Damodar Reddy. Dravyaguna Vignanam, $1^{\text {st }}$ Edition, Dhanvantari Prachuranalu; Hyderabad; November 1987.

15. Madadi Damodar Reddy; Dravyaguna Vignanam; $1^{\text {st }}$ Edition; Dhanvantari Prachuranalu; Hyderabad; November 1987. 